\title{
Dolnośląskie wsie tematyczne - miejsce edukacji i zabawy Lower Silesian thematic villages - place of education and entertainment
}

\author{
Anna Podolska (10 \\ Uniwersytet Przyrodniczy we Wrocławiu, Instytut Architektury Krajobrazu \\ ul. Grunwaldzka 55, 50-357 Wrocław \\ anna.podolska@upwr.edu.pl
}

\begin{abstract}
Zarys treści: Od końca lat 80. XX w. na obszarach wiejskich zauważyć można szereg przemian spowodowanych zarówno czynnikami wewnętrznymi, jak i zewnętrznymi. W znacznym stopniu prowadzą one do zmian dotychczasowych funkcji wsi. Model wsi rolniczej odchodzi coraz częściej w niepamięć, a możliwość utrzymania mieszkańców wsi zapewniają działalności pozarolnicze, które nie tylko oferują nowe miejsca pracy, ale również integrują mieszkańców, mają wpływ na zmianę otoczenia obejść oraz terenów wspólnych, a często również całkowicie zmieniają wizerunek wsi i sposób ich postrzegania. Wsie stają się aktywne, innowacyjne, kreatywne. Pomysły ich mieszkańców dotyczą zarówno działalności ekonomicznej, jak i społecznej i przyczyniają się do szybkiego rozwoju turystyczno-rekreacyjnego regionu. W ostatnich dziesięciu latach na Dolnym Śląsku dużą popularnością cieszy się tworzenie wiosek tematycznych. Dobrze obmyślony motyw przewodni może przynieść korzyści zarówno mieszkańcom, którzy znajdą dla siebie nowe miejsca pracy i dodatkowe źródło dochodu, jak również turystom, którzy często w bliskiej odległości od domu będą mogli ciekawie spędzić czas wolny. Jest to również szansa na regionalną edukację ekologiczną młodzieży i dzieci, które bezpośrednio w terenie mają szansę poznawać i uczyć się otaczającej ich przyrody. Skorzystać może także przestrzeń wiejska, w której świadomi mieszkańcy pielęgnować będą tradycję i miejscową kulturę oraz dbać będą o zachowanie ładu przestrzennego. Celem badań było ukazanie roli, jaką w rozwoju obszarów wiejskich województwa dolnośląskiego pełni nowa funkcja pozarolnicza - wioski tematyczne oraz ich potencjalny wkład w promowanie turystyki edukacyjnej w regionie. Wykorzystano następujące metody badań: analizę literatury źródłowej i danych statystycznych zawartych w księgach meldunkowych, badania ankietowe z liderami wiejskimi oraz analizę dostępnych ofert badanych wsi. Wyniki przedstawione zostały na mapie województwa, wykresach słupkowych oraz w tabeli.
\end{abstract}

Słowa kluczowe: wieś tematyczna, wioska z pomysłem, pozarolnicza działalność gospodarcza, województwo dolnośląskie.

\section{Wstęp}

Podstawową rolą obszarów wiejskich jest dostarczanie społeczeństwu produktów żywnościowych i surowców do przemysłu (Woś i Zegar 2002; Kłodziński 2010). Zdaniem S. Grykienia (2006) tradycyjny rozwój wsi, utożsamiany głównie z rozwojem sektora rolniczego, przechodzi do historii. Przyszłość zaś obszarów wiejskich w Polsce powinna pójść w kierunku wielofunkcyjnego rozwoju. Jak słusznie zauważa J. Wilkin (2010), rozwój rolnictwa 
wiąże się także z innymi pozarolniczymi funkcjami, które odgrywają duże znaczenie zarówno dla środowiska, jak również dla ludzi. W literaturze naukowej pojawia się nowa propozycja klasyfikacji pozakomercyjnych funkcji rolnictwa z podziałem na 4 grupy:

1) Funkcje zielone - zarządzanie zasobami ziemi w celu utrzymania jej wartościowych właściwości, stwarzanie warunków dla dziko żyjących zwierząt i roślin, ochrona dobrostanu zwierząt, utrzymanie bioróżnorodności i poprawa obiegu substancji chemicznych w systemach produkcji rolnej.

2) Funkcje błękitne - zarządzanie zasobami wodnymi, poprawa jakości wód, zapobieganie powodziom, wytwarzanie energii wodnej i wiatrowej.

3) Funkcje żółte - utrzymywanie spójności i żywotności obszarów wiejskich, podtrzymywanie i wzbogacanie tradycji kulturalnych oraz tożsamości wsi i regionów, rozwój agroturystyki.

4) Funkcje białe - zapewnienie bezpieczeństwa żywnościowego i zdrowej żywności (Van Huylenbroeck i in. 2007, za: Wilkin 2010).

Funkcje rolnictwa i obszarów wiejskich związane są z dostarczaniem licznych dóbr prywatnych (w tym usług turystycznych) i publicznych pożądanych przez społeczeństwo, które mają niebagatelny wpływ na różne dziedziny życia (Kutkowska 2012). J. Wilkin (2010) klasyfikuje dobra publiczne wytwarzane przez rolnictwo, określając je jako dobra środowiskowe, dobra ekonomiczne, a także dobra społeczno-kulturowe, w których dużą rolę odgrywa kształtowanie tożsamości lokalnej, regionalnej i kulturowej.

Jak słusznie zauważył J. Zegar (2002), rozwój danego regionu będzie możliwy tylko wówczas, kiedy poza produkcją rolną aktywna stanie się także przedsiębiorczość pozarolnicza. Ważne, aby zapewniła ona nowoczesne formy aktywności zarobkowej (Antoszek i Sobczyk 2004) i położyła duży nacisk na ochronę różnorodności kulturowej i przyrodniczej (Wilkin 2005). Podstawą rozwoju obszarów wiejskich powinny być zatem przedsięwzięcia ukierunkowane na tworzenie nowych źródeł dochodu, tj. rzemiosło, przetwórstwo i usługi (Pałka 2010).

Dzisiejsze obszary wiejskie pełnią liczne funkcje, których znaczenie odgrywa istotną rolę zarówno w skali lokalnej, jak również regionalnej czy krajowej. Funkcje te dotyczą m.in. sfery przestrzennej, środowiskowej, społecznej czy kulturalnej. Choć wieś nadal kojarzona jest z rolnictwem, to jej tradycyjny obraz coraz częściej odchodzi w zapomnienie. Krowy pasące się na łące, ręczne kręcenie powróseł wiążących snopki w czasie żniw, wozy konne zwożące z pola kopy siana czy choćby domowe ptactwo rozbiegane po wiejskich podwórkach stanowią już dzisiaj rzadkość. Także obecność osób rzeczywiście utrzymujących się z rolnictwa jest w poszczególnych wsiach obecnie znikoma. Jak słusznie zauważa W. Idziak (2008), problem ten nie dotyczy wyłącznie polskiej wsi, ale całego świata i nosi nazwę ewolucji sektorów gospodarki, w której najpierw największe znaczenie miał sektor I - bazujący na przyrodzie: rolnictwo, leśnictwo, rybołówstwo, później sektor II - przemysł i budownictwo, a obecnie sektor III - usługi. W tym ostatnim gospodarka ulega „dematerializacji” tzn., że jej podstawą są czynniki niematerialne, np. emocje czy symbole i liczą się tutaj przede wszystkim kapitał kulturowy i ludzki. Na znaczeniu zyskują: wiedza, doznania, rozrywka i twórczość.

Gospodarka oparta na wiedzy to już nie tylko laboratoria czy uczelnie, to również gospodarstwa edukacyjne, ale także wsie tematyczne oferujące różne warsztaty, których ostatnimi laty powstaje coraz więcej. Edukacja może mieć w nich różne profile i dotyczyć przedmiotów przyrodniczych, ale też ścisłych. Kształcenie odbywa się poprzez działanie, 
w którym uczestnik sam bierze udział. Można się tam zaznajomić również z rzemiosłem artystycznym, ziołolecznictwem, dawnymi obyczajami czy sztuką ludową. Biorąc udział w zajęciach edukacyjnych uczestnicy doznają różnych emocji, które powodują, że dany warsztat na długo pozostaje w ich pamięci. Jest to możliwe tylko wtedy, kiedy z biernych widzów zmieniają się w aktywnych uczestników, którzy przez własne działania dostarczają sobie emocji, wrażeń i doznań. Stąd ten rodzaj gospodarki nosi nazwę gospodarki doznań. Wartość emocjonalna zaczyna przeważać tu nad wartością funkcjonalną (Idziak 2008). Jednym z przykładów tego typu działań mogą być questy - gry terenowe, w których uczestnicy przeżywają różne przygody podążając za wskazówkami prowadzącymi do ukrytego „skarbu”. W wielu częściach świata najszybciej rozwijającą się gałęzią gospodarki jest przemysł rozrywkowy - tzw. gospodarka rozrywki. Do niej dołącza gospodarka twórczości, w której liczy się kreatywność i innowacyjność.

Celem badań było ukazanie roli, jaką w rozwoju obszarów wiejskich województwa dolnośląskiego pełni nowa funkcja pozarolnicza - wioski tematyczne oraz ich potencjalnego wkładu w promowanie turystyki edukacyjnej w regionie. W pracy przeanalizowano oferty programowe wiosek tematycznych z wykazaniem elementów bazujących na zasobach lokalnych, które mają w założeniu edukację prowadzoną w sposób przyjemny i niestandardowy, oparty na doznaniach oraz emocjach. Dla realizacji postawionego celu zostały sformułowane pomocnicze pytania, na które odpowiedzi udzielono w części pracy zawierającej wyniki badań:

- Ile osób jest zaangażowanych w funkcjonowanie w sołectwie wioski tematycznej i czy może ona stanowić alternatywne źródło dochodu?

- Czy osoby obsługujące wioskę tematyczną mogą w niej znaleźć zatrudnienie przez cały rok?

- Skąd są turyści, jaki przedział wiekowy dominuje?

- W jaki sposób wsie się promują i skąd potencjalny turysta może się dowiedzieć o funkcjonowaniu wsi i dostępnym programie?

- Jaką formę mają proponowane atrakcje i do kogo są skierowane (grupy zorganizowane, osoby indywidualne)?

- Jakie profile edukacyjne są poruszane w ofercie wsi?

- Czy aspekt edukacyjny ma wymiar stacjonarny (np. warsztaty), czy jest zauważalny w układzie przestrzennym wsi (m.in. ścieżki edukacyjne, gry terenowe itp.)?

Podstawowymi metodami pracy były: analiza literatury źródłowej oraz danych statystycznych (zebranych z ksiąg meldunkowych badanych wiosek), a także badanie ankietowe przeprowadzone z liderami wiejskimi oraz analiza ofert badanych wsi prezentowanych na stronie internetowej www.wioskizpomyslem.pl. Do badań wybrano tylko wsie tematyczne prezentowane na tej witrynie. Dzięki funkcjonowaniu na jednej platformie są łatwo rozpoznawalne i możliwe do szybkiego odnalezienia dla potencjalnego turysty, a co ważne oferują bogaty program. Obecnie na stronie www.wioskizpomyslem.pl umieszczonych jest 17 wsi tematycznych. Ich oferty zostały zweryfikowane przez autorkę w rozmowach telefonicznych z liderami poszczególnych wiosek w czerwcu 2018 r., podczas których zadano przygotowane wcześniej w formie kwestionariusza pytania. Kwestionariusz ankiety zawierał m.in. wyżej wymienione pytania, a ponadto pytano o: liczbę turystów korzystających z oferty, miesiące najbardziej aktywne, zawartość oferty, z której można korzystać zarówno indywidualnie (tablice edukacyjne, ścieżka edukacyjna, ścieżka zmysłów, questy, czy geocatching), jak i w sposób zorganizowany (oprowadzanie po wsi, zwiedzanie najbliższej 
okolicy, gry terenowe, zabawy ruchowe bazujące na tematyczności wsi, wykłady, pogadanki, szkolenia, wystawy stacjonarne, stałe lub czasowe, minimuzea, izby pamięci, święta lokalne), a także pytano, czy wieś współpracuje z zagrodami edukacyjnymi lub miejscowymi rolnikami oferującymi lokalne produkty. Przedstawione dane zostały zaprezentowane za rok 2017/2018.

\section{Wieś tematyczna jako forma turystyki edukacyjnej}

Coraz częściej wiodącą gałęzią światowej gospodarki, dającą znaczące wpływy do budżetu wielu krajów jest turystyka (Pałka 2010). Stwarza ona możliwości rozwoju małych i średnich przedsiębiorstw, sprzyja powstawaniu nowych miejsc pracy oraz rozwojowi innych form działalności gospodarczej (tj. handel, inne usługi, rzemiosło) na terenach rolniczych (Sala 2006). Najłatwiej turystyka rozwija się bez wątpienia w regionach odznaczających się dużymi walorami turystycznymi z odpowiednio przygotowanymi usługami i infrastrukturą. Co zatem z terenami, które nie odznaczają się wysokimi walorami przyrodniczymi czy architektonicznymi, mają często peryferyjne położenie, a ich zwykle jedyną mocną stroną są aktywni, pełni pasji mieszkańcy? Dla tych terenów od kilkunastu lat również pojawiła się możliwość rozwoju, która wywodzi się z turystyki wiejskiej i może mieć formę turystyki edukacyjnej (Czapiewska 2018), a mianowicie wioski tematyczne. Są one przykładem innowacji w turystyce wiejskiej, która określana jest jako „innowacje sprzężone”. To znaczy, że przy ich powstaniu biorą udział zarówno społeczności lokalne, jak również podmioty lokalne czy ponadlokalne (Sikorska-Wolak i in. 2016). Jak zauważa S. Salamon (2006), wiejskość i „rolniczość” stają się czymś modnym, na czym można zarobić. Wieś stała się atrakcyjnym miejscem do spędzenia wolnego czasu, zarówno krótkiego - weekendowego, jak również dłuższego - wakacyjnego. Atrakcją są tam na pozór zwykłe rzeczy, tj. domostwa, ich otoczenie, zwierzęta, czy nawet sami mieszkańcy (Woods 2005). Wioski tematyczne to ciekawe inicjatywy lokalne, które mogą wzbogacić rozwój społeczno-gospodarczy wsi. Są również sprawdzoną i skuteczną metodą aktywizowania obszarów wiejskich i ożywienia ich gospodarki. Mogą stanowić alternatywne źródło dochodu oraz zapewnić mieszkańcom dodatkowe miejsca pracy, bazując przy tym na ich pomysłach i umiejętnościach (Czapiewska 2012, 2018).

Wsie tematyczne to nowa forma odpoczynku dla osób z miasta spragnionych kontaktu z przyrodą, a także forma poznania tradycji czy kultury wiejskiej. To także idealne miejsce na spędzenie wolnego czasu, organizacji „zielonych szkół” czy lekcji w terenie.

Dla mieszkańców miast wieś to coraz częściej doskonałe miejsce do edukacji i zabawy, zarówno tej indywidualnej weekendowej, jak również organizowanej w ramach zajęć szkolnych czy przedszkolnych. To tutaj możemy bezpośrednio obcować z przyrodą, zgłębić tajniki uprawy roślin czy hodowli zwierząt, poznać tradycję, miejscową kulturę czy dawne rzemiosło. Wiedza przyswajana jest całościowo, poprzez działanie, w sposób namacalny, łatwo przystępny, ciekawy i niestandardowy.

Wraz z rozwojem wsi tematycznych zaczęła nabierać znaczenia funkcja edukacyjna wsi i gospodarstwa wiejskiego. Zaplecze edukacyjne stanowią bowiem często zaadaptowane budynki gospodarcze (stodoły, obory, stajnie, szopy, spichlerze, magazyny itp.) i budynki służące przetwórstwu (młyny, serowarnie, dojrzewalnie, domowe piekarnie, pracownie pszczelarskie itp.), a także rzemiosłu. Dzieci z miasta często nie wiedzą jak wygląda krowa, 
czy inne typowe niegdyś dla polskiej wsi zwierzęta. Nie zdają sobie również często sprawy z tego, skąd bierze się mleko czy chleb, nim pojawią się w sklepie. Coraz częściej wioski tematyczne posiadają rozbudowaną ofertę edukacyjną dla grup dzieci i młodzieży w formie edukacji przez zabawę. Dzieci poznają zwierzęta gospodarskie - ich charakterystykę i wymagania, a także uprawy rolnicze i prace gospodarskie. Dowiadują się, jak wygląda cykl powstania gotowego produktu, np. chleba (popularne są warsztaty „od ziarenka do bochenka”) czy masła. Mogą poznać smak naturalnych wiejskich produktów, tj. mleka prosto od krowy czy kozy, śmietany, miodu bezpośrednio z pszczelego plastra, warzyw prosto z grządki, owoców z krzaka, ziół z przydomowego warzywnika czy domowego pieczywa z pieca chlebowego. Jest to z pewnością połączenie przyjemnego z pożytecznym, które rozbudzi w dzieciach ciekawość poznania świata.

Wieś staje się w ostatnich latach coraz bardziej popularna. Jej odkrywanie odbywa się często w oparciu o nową formułę ewolucji turystyki 3E bazującej na rozrywce (entertainment), ekscytacji (excitement) oraz edukacji (education). Powstające atrakcje mają za zadanie bawić, ekscytować, ale również edukować poprzez pobudzanie do myślenia i refleksji (Kruczek 2011, s. 49). Takim celom rozrywkowo-edukacyjnym służą m.in. powstałe wsie tematyczne. Dzięki właściwej oprawie, możliwej poprzez przebywanie w środowisku przyrodniczym, uczestniczeniu w codziennym „życiu” gospodarstwa oraz życiu społecznym czy kulturalnym danej społeczności wiejskiej, współczesna wieś może pełnić istotne funkcje edukacyjne. Funkcje te dodatkowo opierają się o pozostałe 2 idee, czyli rozrywkę, która sprawia, że przyswajanie wiedzy nie jest nudne, a do tego łatwo przystępne, często w postaci zabawy oraz o ekscytację - doznania, które towarzyszą zdobywaniu wiedzy. Funkcja edukacyjna wsi jest dziedziną jeszcze słabo rozpoznaną. Głównie kojarzona jest ona z turystyką, czy specjalizacją gospodarstw agroturystycznych. Te drugie często przekształcają się w zagrody edukacyjne czy ekomuzea, bądź rozszerzają działalność na większy obszar, tworząc bazę pod specjalizację dla całej miejscowości.

Edukacja w wioskach tematycznych nie jest typowa, ani taka, do której jesteśmy przyzwyczajeni w szkole. Tutaj „budynkiem szkolnym” jest sama natura - lasy, pola, łąki, czy też przestrzeń wiejska, a zamiast książek są żywe rośliny czy zwierzęta. W rolę osób dzielących się wiedzą wcielają się najczęściej sami mieszkańcy wsi. Taki bezpośredni kontakt ze środowiskiem przyrodniczym, ale także społeczno-kulturowym, prócz cennych wartości poznawczych, dostarcza także wielu przeżyć emocjonalnych. Najliczniejszą grupą korzystającą z zajęć organizowanych we wsiach tematycznych są dzieci w wieku przedszkolnym i wczesnoszkolnym. Ale programy edukacyjne są dostosowane do różnych grup wiekowych, również dorosłych. Dla najmłodszych najkorzystniejszą i najbardziej atrakcyjną formą edukacji jest zabawa. W ten sposób dzieci odkrywają wieś oraz poznają rośliny i zwierzęta, które mogą samodzielnie dotknąć i zobaczyć na żywo. Często również sami mieszkańcy wsi muszą się wcześniej doszkalać, uczestniczyć w kursach czy w szkoleniach, aby następnie móc przekazywać zdobytą wiedzę dalej. W niektórych krajach bez odpowiedniego szkolenia nie można prowadzić zajęć edukacyjnych w swoich gospodarstwach. Taki wymóg istnieje m.in. w Austrii, gdzie każdy usługodawca chcący przyjmować w swoim gospodarstwie dzieci, musi ukończyć kurs przygotowania pedagogicznego oraz uzyskać odpowiedni certyfikat (Czarnecka 2007).

We wsiach tematycznych często do oferty włączane są zajęcia tematyczne w zaprzyjaźnionym gospodarstwie (zagrodzie edukacyjnej). Zdarza się również, że to właśnie tworzenie wsi tematycznej opiera się na takim jednym punkcie we wsi, a dopiero z czasem, 
kiedy zaangażowanie mieszkańców wzrasta, rozszerza się na inne fragmenty miejscowości. W zagrodach edukacyjnych realizowane mogą być różne cele edukacyjne z zakresu produkcji roślinnej i przetwórstwa płodów rolnych, hodowli zwierząt, świadomości ekologicznej, dziedzictwa kultury materialnej wsi, tradycyjnych zawodów, rękodzieła (Sikorska-Wolak i Zawadka 2014)

W związku z pogarszającym się stanem środowiska naturalnego ważne jest, aby już od najmłodszych lat wpajać dzieciom potrzebę jego ochrony i uczyć ich wrażliwości na środowisko, gdyż to właśnie dzieci cechuje największa wrażliwość na otoczenie zewnętrzne, w tym przyrodę (Budniak 2009). E. Buchcic (2014) zwraca uwagę, że najłatwiej jest trwale zainteresować dzieci otaczającą je przyrodą i zjawiskami w niej zachodzącymi, jeśli mają one z nimi bezpośredni kontakt. Wówczas budzą się w nich stałe uczucia, gdyż prócz obserwatora mogą wykazać się również cechami opiekuńczymi. Wytwarza to także pozytywny stosunek do środowiska i ułatwia powstanie pozytywnych związków i uczuć względem niego. Kontakt dzieci z przyrodą jest bardzo istotny dla ich rozwoju. Wpływa on m.in. na rozwój umysłowy, rozwój mowy, wyobraźni oraz proces myślenia. Pobudza do rozmyślania, wzbogaca zasób słownictwa, a także sprzyja rozwojowi uczuć wyższych i zdolności intelektualnych. Obcowanie ze środowiskiem wzbogaca osobowość, sprzyja nauczaniu odróżniania dobra od zła oraz wykształca wartości moralne i różne umiejętności. Sprzyja również rozwojowi ruchowemu i sprawnościowemu dzieci poprzez udział w różnych wycieczkach czy zajęciach terenowych (Buchcic 2014). Podczas nauczania o środowisku dzieci nabywają odpowiedniego zachowania zarówno w relacjach z drugim człowiekiem, jak również wobec przyrody. Ważne jest, aby te cechy nabywać od najmłodszych lat, gdyż im wcześniej są one kształtowane, tym odznaczają się wyższym stopniem trwałości (Buchcic 2014). Każde dziecko z natury jest badaczem. Jego ciekawość i chęć poznania otaczającego świata jest bardzo silna. Choć młody człowiek nie zna jeszcze procedur badawczych, w sposób naturalny eksploruje otoczenie. Opisowe nauczanie o przyrodzie jest zatem niewystarczające. Ważna jest przy tym aktywność poznawcza dziecka. Dlatego warto poszukiwać coraz to nowszych rozwiązań, które wprowadzone bezpośrednio w terenie, przybliżą dzieciom w ciekawy i namacalny sposób otaczającą je przyrodę. Innowacyjną formą edukacji przyrodniczej są m.in. wioski tematyczne. Ich bezpośredni kontakt z uczestnikiem warsztatów tematycznych oraz otwarta forma prowadzonych zajęć sprzyjają bezpośredniemu kontaktowi z przyrodą.

\section{Charakterystyka badanych wsi pod kątem szerzenia edukacji}

Przyjęte do badań wsie tematyczne położone są w różnych powiatach województwa dolnośląskiego: wrocławskim (1), trzebnickim (1), kłodzkim (1), jaworskim (1), jeleniogórskim (1), złotoryjskim (1), bolesławieckim (4), zgorzeleckim (1), legnickim (3), dzierżoniowskim (1) i polkowickim (2) (ryc. 1).

W województwie dolnośląskim działa spora ilość wsi tematycznych, ale niestety większość z tych ofert nie jest łatwo dostępnych (Podolska i Niedźwiecka-Filipiak 2017). Najczęściej promują się one poprzez portale społecznościowe (facebook) i nie posiadają własnej strony internetowej. Jak dowodzą badania prowadzone przez A. Podolską (2018), wioski tematyczne na Dolnym Śląsku są na różnym etapie rozwoju i wiele z nich działa głównie wewnętrznie i sprzyja przede wszystkim integracji mieszkańców, nie mając przy tym roz- 


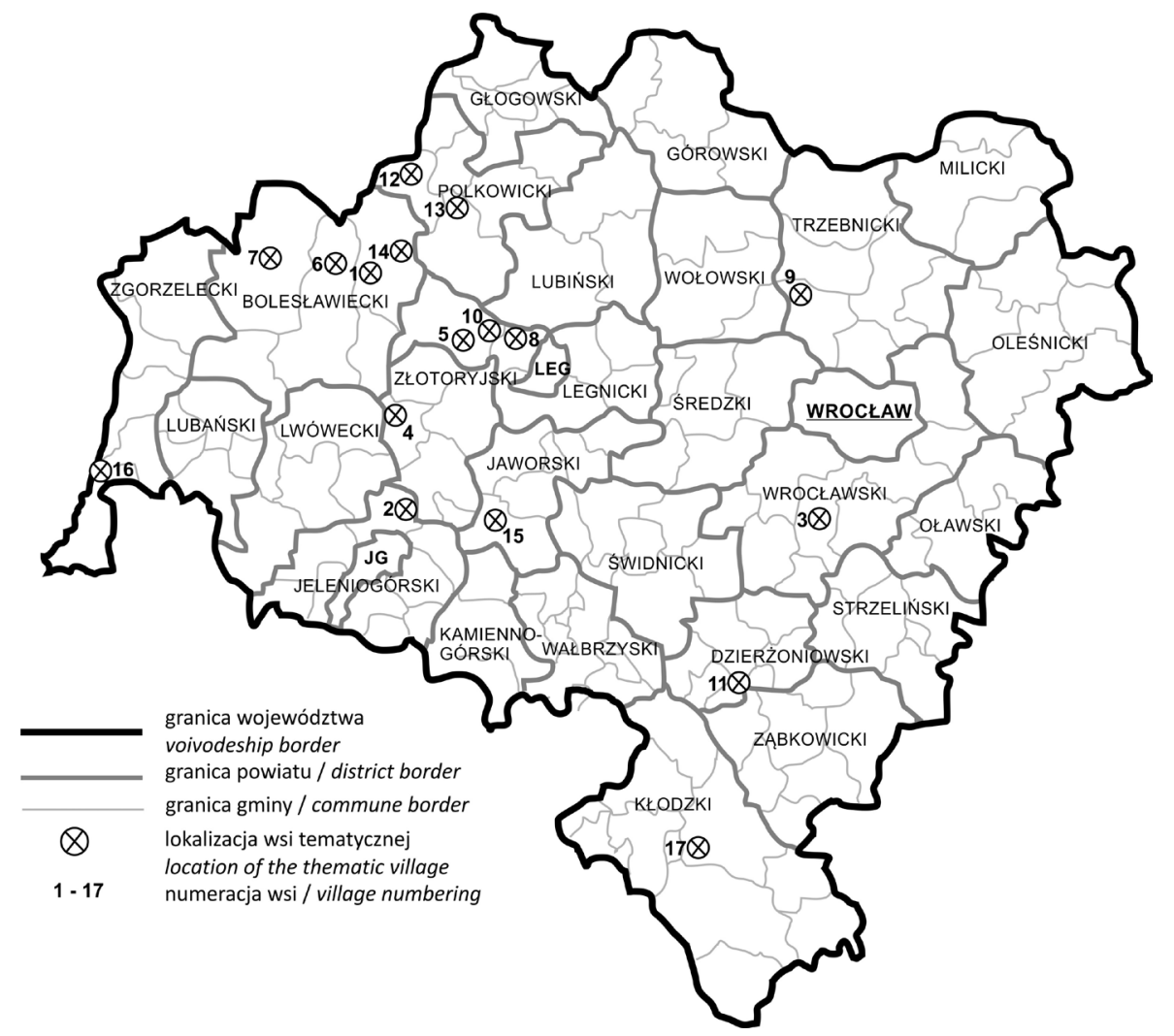

Ryc. 1. Lokalizacja badanych wsi tematycznych

1 - Borówki, 2 - Chrośnica, 3 - Chrzanów, 4 - Czaple, 5 - Konradówka, 6 - Lipiany, 7 - Ławszowa, 8 - Miłkowice, 9 - Morzęcin Mały, 10 - Niedźwiedzice, 11 - Owiesno, 12 - Ostaszów, 13 - Parchów, 14 - Pasternik, 15 - Radzimowice, 16 - Spytków, 17 - Stary Wielisław Źródło: opracowanie własne, tak samo pozostałe ryciny. Location of the studied thematic villages Source: author's own elaboration, as remaining figures.

budowanej oferty komercyjnej. Ich oferta często bazuje na atrakcjach, z których turysta może skorzystać samodzielnie, bez konieczności korzystania z pomocy „przewodnika”.

Poza wizualnymi elementami rozmieszczonymi w przestrzeni wiejskiej turysta nie ma dostępu do pełnej informacji o atrakcjach. Dużym problemem jest tu również bardzo słaba promocja albo nawet, jak to dotyczy wielu miejscowości, jej zupełny brak. Przez co ciekawy często pod względem edukacyjnym program jest dostępny jedynie dla umówionych wcześniej grup studyjnych, a nie dla „zwykłego turysty”, który po prostu nie ma świadomości istnienia danej wsi tematycznej (informacja uzyskana od liderów wiejskich).

Badane wsie są zrzeszone na wspólnej platformie www.wioskizpomyslem.pl, która jest wysoko pozycjonowana w wyszukiwarkach internetowych, dzięki czemu po wpisaniu hasła „wioski tematyczne na Dolnym Śląsku” wyświetla się ona jako pierwsza. Z rozmowy z założycielem tej strony autorka dowiedziała się, że przeprowadzono selekcję, na pod- 
stawie której wybrano do umieszczenia na platformie jedynie tych najaktywniejszych, którzy posiadają ofertę, z której rzeczywiście turysta może skorzystać przebywając w danej miejscowości. Do niedawna strona miała aktywne linki do 35 wsi, dziś pozostało ich jedynie 17 (dane na dzień 30.06.2018). Udało się nawiązać kontakt z wszystkimi wioskami. Jak się okazało podczas rozmowy z założycielem jednej z atrakcji utworzonej we wsi Ostaszów, wieś ta nie funkcjonuje obecnie jako wieś tematyczna (chociaż w taki sposób została nawet określona w aktualnym folderze informacyjnym umieszczonym na stronie www.wioski.wrzosowakraina.pl). Nazwa - Wioska w Dechę, nawiązywała do historycznej zabudowy szachulcowej, która w obecnej ofercie jest zupełnie niezauważalna. Działają w niej niezależne i niezwiązane tematycznie atrakcje tj. gospodarstwo agroturystyczne z minizoo, wioska indiańska oraz obozowisko rycerskie. Dlatego w dalszych badaniach nie wzięto tej wsi pod uwagę.

Poziom aktywności wsi i tym samym popularności wśród turystów jest mocno zróżnicowany. Są wsie, które rocznie odwiedza do 100 osób, ale są też takie, które mają kilka tysięcy turystów rocznie (ryc. 2).

Realizowane w 16 badanych miejscowościach cele edukacyjne posiadają różne profile. Opierają się one na obranej specjalizacji, która bazuje na: nazwie wsi (1), rzemiośle (1), tradycji/zwyczajach (1), historii/legendzie (2), przyrodzie (5), umiejętnościach mieszkańców (2), czy nowym pomyśle (4). Podobnie jak specjalizacja, tak również sama oferta edukacyjna jest bardzo zróżnicowana w poszczególnych wsiach. Składają się na nią m.in. warsztaty przeprowadzane w poszczególnych miejscowościach tematycznych. W każdej z badanych wsi stanowią one ofertę płatną, z której można skorzystać po uprzednim umówieniu się. Warsztaty edukacyjne oferowane w badanych wsiach można podzielić w zależności od tematu na 8 rodzajów (tab. 1).

Wsie tematyczne konkurują między sobą, wymyślając coraz to nowe tematy warsztatów. Każda z wsi "chce” być oryginalna i innowacyjna, ciekawsza od innych wiosek, aby stać się celem odwiedzin. Oferta wsi tematycznych, w zależności od opracowanego programu, bazującego na obranej specjalizacji, może składać się z różnych elementów. Ich zasadą jest czynny udział uczestników w oferowanych atrakcjach. Najliczniej pojawiają się

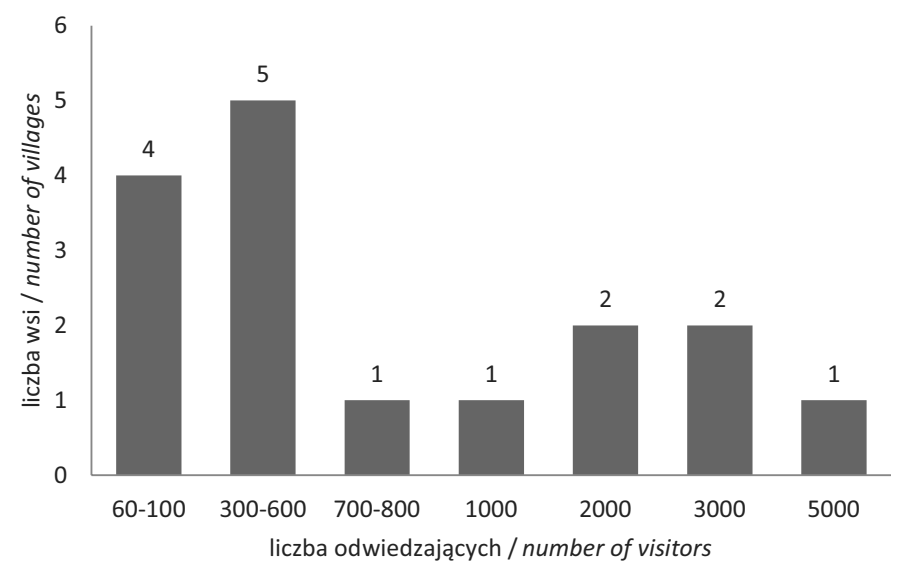

Ryc. 2. Liczba osób korzystających z płatnej oferty w ciągu roku w badanych wsiach Number of visitors using paid offer in the studied villages per year 
Tabela 1. Rodzaje warsztatów oferowanych w badanych wsiach wraz z przykładowym programem zajęć

\begin{tabular}{|c|c|c|}
\hline $\begin{array}{c}\text { Rodzaje } \\
\text { warsztatów }\end{array}$ & Przykładowy program & Miejscowość \\
\hline Artystyczne & $\begin{array}{l}\text { wykręcanie z siana, robienie pieczątek z „natury”; tworzenie } \\
\text { barwnej mozaiki bociana z kawałeczków liści, płatków, ziemi, } \\
\text { kory, łodyg, piórek; tworzenie ziołowych kompozycji w formie } \\
\text { obrazu; robienie kwiatów i innych ozdób z krepiny; zdobienie } \\
\text { ramek lub kartek metodą scrapbookingu połączonego z lo- } \\
\text { kalnymi kruszywami; tworzenie dekoracji z roślin naturalnych } \\
\text { i z piaskowca; malowanie wybranych bajkowych motywów } \\
\text { na kamieniach; tworzenie naszyjników bądź bransoletek przy } \\
\text { użyciu sznurka i kamienia }\end{array}$ & $\begin{array}{l}\text { Chrzanów, Czaple, Kon- } \\
\text { radówka, Ławszowa, } \\
\text { Miłkowice, Morzęcin } \\
\text { Mały, Niedźwiedzice, } \\
\text { Owiesno Parchów, } \\
\text { Pasternik, Radzimo- } \\
\text { wice, Spytków, Stary } \\
\text { Wielisław }\end{array}$ \\
\hline Kulinarne & $\begin{array}{l}\text { pieczenie ciast z lokalnych produktów, dobieranie odpowied- } \\
\text { nich kompozycji ziołowych do olejów smakowych (do mięs } \\
\text { i sałatek), dekorowanie ciast z masy marcepanowej; piecze- } \\
\text { nie podpłomyków na kamieniu; gotowanie z wykorzystaniem } \\
\text { warzyw i owoców sezonowych }\end{array}$ & $\begin{array}{l}\text { Borówki, Chrzanów, } \\
\text { Czaple, Lipiany Morzę- } \\
\text { cin Mały, Niedźwiedzi- } \\
\text { ce, Owiesno Parchów, } \\
\text { Radzimowice, Spytków, } \\
\text { Stary Wielisław }\end{array}$ \\
\hline Zielarskie & $\begin{array}{l}\text { komponowanie woreczków zapachowych, tworzenie olejków } \\
\text { aromatycznych do kąpieli }\end{array}$ & $\begin{array}{l}\text { Borówki, Chrośnica, } \\
\text { Spytków }\end{array}$ \\
\hline $\begin{array}{l}\text { Związane z daw- } \\
\text { nym rzemiosłem }\end{array}$ & $\begin{array}{l}\text { poznanie tradycyjnych metod uprawy i obróbki Inu po- } \\
\text { przez wspólne tworzenie włókna Inianego tradycyjnymi } \\
\text { narzędziami }\end{array}$ & Chrośnica \\
\hline $\begin{array}{l}\text { Związane z życiem } \\
\text { w gospodarstwie, } \\
\text { np. hodowla by- } \\
\text { dła, uprawa roślin }\end{array}$ & $\begin{array}{l}\text { wizyta w gospodarstwie rolnym - zagrodzie edukacyjnej; } \\
\text { poznawanie zwierząt i zasad bezpiecznego obchodzenia się } \\
\text { z nimi }\end{array}$ & $\begin{array}{l}\text { Chrośnica, Chrzanów, } \\
\text { Konradówka, Radzimo- } \\
\text { wice, Spytków }\end{array}$ \\
\hline Ogrodnicze & $\begin{array}{l}\text { przygotowanie gleby, wysiew nasion, sadzonek, podlewanie, } \\
\text { pielenie, przerywanie, zbieranie plonów w Ogrodzie Zmysłów } \\
\text { i Smaków }\end{array}$ & Chrzanów \\
\hline Botaniczne & $\begin{array}{l}\text { poznawanie i rozpoznawanie gatunków drzew, krzewów, } \\
\text { kwiatów i ziół; edukacyjny spacer po ziołowym ogrodzie } \\
\text { z zielarką - pogadanka o ziołach i ich zastosowaniu w życiu } \\
\text { codziennym; poznanie roślin z właściwościami barwiącymi }\end{array}$ & Radzimowice \\
\hline Meteorologiczne & $\begin{array}{l}\text { wizyta w ogródku meteorologicznym, warsztaty edukacyjne } \\
\text { z zakresu klimatu i zjawisk pogodowych: symulatory zjawisk } \\
\text { i ciekawe doświadczenia }\end{array}$ & Pasternik \\
\hline
\end{tabular}

Źródło: opracowanie własne na podstawie wywiadów z liderami wiejskimi i www.wioskizpomyslem.pl.

w ofertach warsztaty artystyczne (34\%) i kulinarne (29\%). Najrzadziej (pojedynczo) - botaniczne, ogrodnicze i meteorologiczne (ryc. 3).

Tematy warsztatów mogą być dostosowane do różnych grup odbiorców, ale jak wynika z rozmów z liderami poszczególnych wiosek, głównymi odbiorcami oferty są dzieci szkolne i przedszkolne (69\%), które do większości miejscowości przyjeżdżają z sąsiadujących gmin. 1/4 pytanych liderów wiejskich zadeklarowała, że najczęściej odwiedzają ich dzieci oraz seniorzy, tylko w 1 wsi odbiorcami są głównie dorośli w wieku produkcyjnym. Zaledwie 1/3 wsi odwiedzają osoby z odległych części województwa lub nawet z innych regionów Polski.

Poza warsztatami, które oferowane są w każdej z badanych wsi, można znaleźć jeszcze inne, ciekawe pod kątem edukacji przez zabawę, punkty programu tematycznego (ryc. 4), które wymieniono poniżej. 


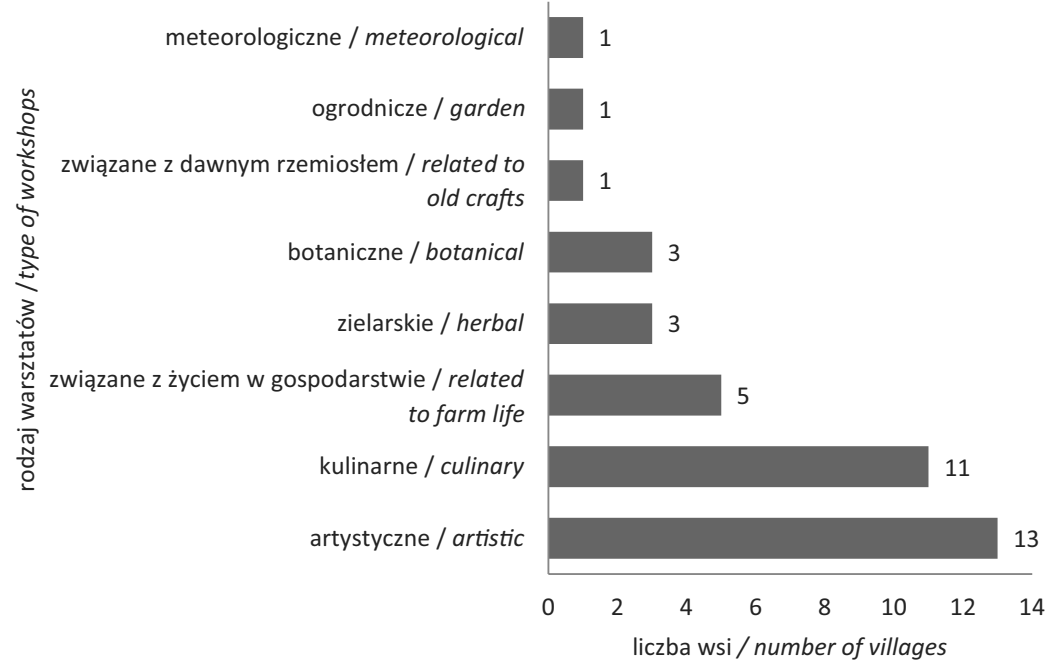

Ryc. 3. Rodzaje oferowanych warsztatów Types of workshops offered

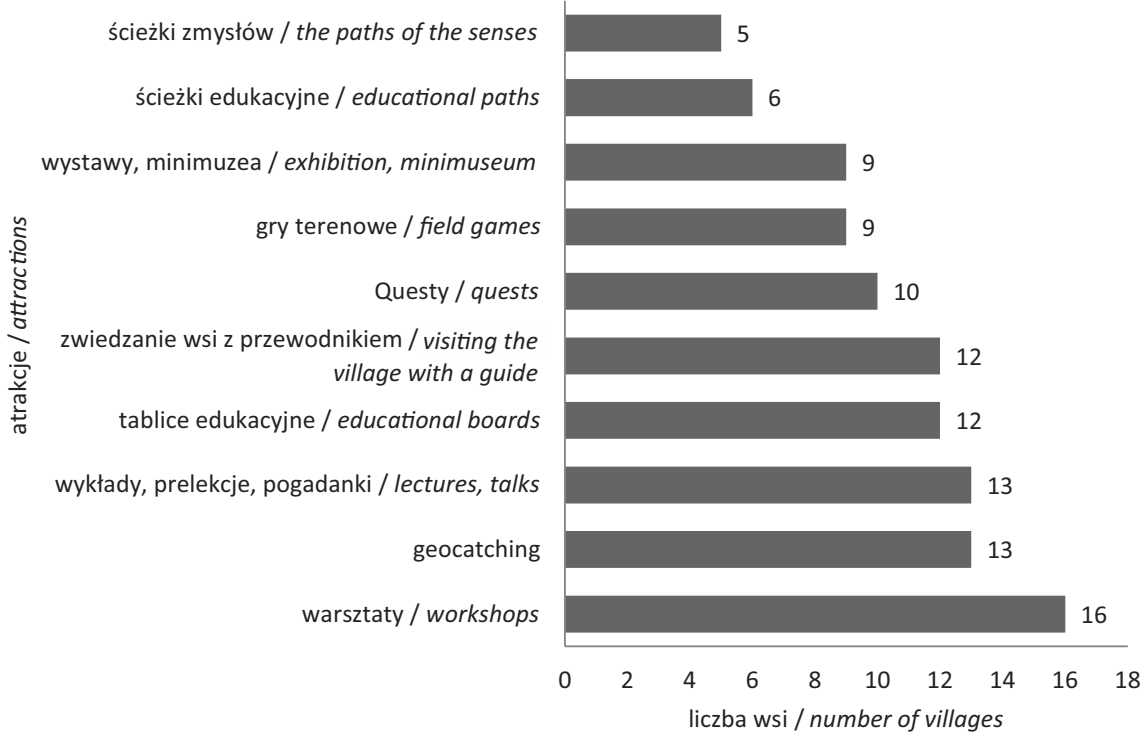

Ryc. 4. Oferowane atrakcje o charakterze edukacyjnym Offered educational attractions

- Questy - wyprawy odkrywców: edukacyjne gry terenowe, będące ciekawą pomocą w odkrywaniu i promocji danego miejsca w oparciu o lokalne dziedzictwo kulturowe, przyrodnicze i historyczne. Tworzą je nieoznakowane w terenie trasy, po których porusza się na podstawie wierszowanych wskazówek. Oferuje je 63\% wsi. 
- Gry terenowe - gry rozgrywane w czasie rzeczywistym, w terenie, posiadające aspekt edukacyjny. Oferuje je 56\% wsi.

- Ścieżki edukacyjne - trasy przyrodnicze wytyczone w atrakcyjnych miejscach i opatrzone w tablice edukacyjne. Występują w 6 miejscowościach (38\%), ale kolejne 4 wsie planowały ich utworzenie do $2019 \mathrm{r}$.

- Ścieżki zmysłów - polisensoryczne poznawanie świata poprzez chodzenie na boso po różnych naturalnych nawierzchniach utworzonych, np. z piasku, kamieni o różnej frakcji i obtoczeniu, szyszek itp. Są najrzadziej występującą atrakcją, posiada je $31 \%$ wsi.

- Tablice edukacyjne. Posiada je 75\% wsi.

- Geocatching - zabawa w poszukiwanie skarbów za pomocą odbiornika GPS. Ideą przewodnią jest znalezienie ukrytego wcześniej w terenie pojemnika (skrytki cache) i odnotowanie tego faktu na specjalnej stronie internetowej. Najczęściej skrytki zakłada się w miejscach atrakcyjnych turystycznie lub eksponujących walory miejscowości. Ciekawym pomysłem może pochwalić się wieś Niedźwiedzice, która poszczególne skrzynki ma tak rozmieszczone, aby z lotu ptaka dały one obraz bociana nawiązującego do motywu przewodniego wsi tematycznej. Skrytki posiada aż $81 \%$ wsi.

- Wystawy stacjonarne, czasowe, minimuzea, izby pamięci. Funkcjonują w ponad połowie badanych wsi.

- Zwiedzanie wsi (w tym przez grupy) z przewodnikiem, którym jest mieszkaniec-pasjonata. Można się wówczas zaznajomić zarówno z architekturą, jak również ze środowiskiem przyrodniczym miejscowości. Taka możliwość występuje w 75\% wsi.

- Wykłady, prelekcje, pogadanki - w ramach warsztatów turysta może także posiąść fachową wiedzę na dany temat. Wśród ofert przedstawionych przez badane miejscowości przeważa tematyka związana z poznawaniem i rozpoznawaniem gatunków roślin, ale są również pogadanki z zakresu klimatu i zjawisk pogodowych, a także dotyczące życia zwierząt gospodarskich, czy uprawy zbóż, np. orkiszu. Często jednak najpierw sami mieszkańcy wsi się doszkalają, aby w profesjonalny sposób móc rozmawiać na tematy związane z obraną specjalnością i móc w pełni edukować przybyłe grupy.

Ze względu na to, że głównymi odbiorcami ofert są dzieci przedszkolne i młodzież szkolna, znaczna część wiosek posiada w swoim programie zajęcia rekreacyjno-sportowe, w dużej mierze oparte na tematyczności wsi. Zajęcia tego typu mogą stanowić uatrakcyjnienie części edukacyjnej. Mogą mieć one charakter gier i zabaw integracyjnych, których nazwa wiąże się ze specjalizacją wsi, np. „bycza olimpiada na pastwisku w Konradówce" - Rogatej Wsi, bocianie igrzyska - gry i zabawy ruchowe w Niedźwiedzicach - Wiosce Bociana, czy w Czaplach - Wiosce Piasku i Kamienia, „olimpiada Flinstonów” - gry i zabawy integracyjne nawiązujące do popularnej kreskówki z bohaterami z epoki kamienia łupanego, m.in. wyścigi autem Flinstonów, przeciąganie liny czy rzut kamieniem do celu. Niezależnie od tematu wszystkie zajęcia prowadzone są z wykorzystaniem metod aktywizujących (tj. m.in. wypiekanie regionalnych przysmaków, wykonywanie woreczków zapachowych, mydełek, prace manualne itp.), które aktywnie angażują odbiorcę w poszczególne punkty programu.

W części wsi tematycznych prowadzone są zajęcia, które mają na celu kształtować w najmłodszych świadomość i wrażliwość ekologiczną, a także zapoznać ich z życiem 
na wsi i kulturą ludową. Dobrym przykładem będzie tutaj np. Chrośnica - Wioska Barwnych Wątków, która wprowadza turystę w tajniki naturalnego barwienia, pomaga poznać rośliny o właściwościach barwiarskich, a ponadto zaznajamia z tradycyjnymi metodami uprawy i obróbki Inu dawnymi narzędziami.

Taka możliwość edukacji w autentycznym środowisku wiejskim sprawia, że zajęcia edukacyjne oferowane we wsiach tematycznych są doskonałą formą uzupełniającą obligatoryjny program nauczania szkolnego. Dodatkowym atutem jest wykorzystanie w edukacji pozaszkolnej różnych sfer - poznawczej, emocjonalnej i działania, w których turysta musi coś zobaczyć, dotknąć i przeżyć, aby pozostało to na długo w jego pamięci i spowodowało, że będzie chciał jeszcze do tego miejsca wrócić, czy polecić go znajomym. Jak dowodzą zebrane podczas rozmów z liderami wiejskimi dane, najlepszą reklamą jest tzw. reklama „szeptana”, która sprowadzi do wioski kolejnych chętnych. Z takiej formy pozyskiwania klientów korzystają m.in. 3 wsie, które mogą poszczycić się największą liczbą odwiedzających: Borówki, Morzęcin Mały, Ławszowa (od 2 do nawet 5 tys. rocznie) (rozmowy z liderami wiejskimi). Blisko 95\% wsi promuje się przede wszystkim poprzez facebooka, niektóre wsie promują się w okolicznych szkołach czy przedszkolach poprzez ulotki czy foldery. Prawie połowa wsi ma stworzoną osobną stronę internetową. Dobrą formą reklamy, a ponadto możliwością poznania wiejskiego życia wspólnotowego, często również miejscowej tradycji czy kultury są święta lokalne organizowane cyklicznie przez poszczególne sołectwa. Wśród badanych wsi część deklarowała funkcjonowanie na ich terenie takiego święta, które często było podwaliną pod założenie we wsi wioski tematycznej. Bezpośrednio ze specjalizacją wsi związane są święta lokalne w 7 badanych miejscowościach (Borówki - Święto Wrzosu, Lipiany - Bałkańskie Święto Pity, Morzęcin Mały - Święto Szpinaku, Niedźwiedzice - Piknik pod Bocianim Gniazdem, Owiesno - Spotkanie z Kulturą na Zamku w Owieśnie). W 5 wsiach święto ma charakter kościelny (np. odpust organizowany w dzień patrona Kościoła) czy patriotyczny. Pozostałe 4 wsie nie posiadają w swoim kalendarzu takiej imprezy.

Wieś tematyczna to nie tylko miejsce edukacji i zabawy dla przyjezdnych, przynosi ona również korzyści samym sołectwom. Aktywne wsie nie tyko bardziej dbają o swój wygląd, są czyste i zadbane, wprowadzają ujednolicony system informacji przestrzennej, m.in. numeracja domów, drogowskazy wewnętrzne, tablice informacyjne itp. (np. Czaple, Ławszowa), ale również umożliwiają zdobycie dodatkowego źródła dochodów i organizują choćby dorywcze miejsce pracy dla lokalnej społeczności. Badane wsie angażują w obsługę swojej oferty zwykle kilka osób. Większość z nich ma aktywnych do 5 osób, tylko 2 wsie zadeklarowały, że angażuje się u nich w działanie wsi tematycznej nawet 15 osób. Zaangażowanie i dbanie o ład przestrzenny ułatwia sołectwom aktywny udział w organizowanym od 10 lat przez Urząd Marszałkowski Województwa Dolnośląskiego (UMWD) konkursie „Piękna Wieś Dolnośląska”. Z pośród badanych miejscowości sukcesy w tym konkursie odniosła ponad połowa wsi (informacja na podstawie danych z UMWD):

- kategoria „Najpiękniejsza Wieś Dolnośląska”: Radzimowice - III miejsce w 2009 r., Parchów - wyróżnienie w 2009 r., Spytków, Czaple, Niedźwiedzice - laureaci I miejsca kolejno w latach 2014, 2015 i 2017 w, Ławszowa - II miejsce w 2016 r.;

- kategoria "Najlepszy Start w Odnowie Wsi”: Morzęcin Mały - III miejsce w 2014 r., Chrośnica II miejsce w 2017 r.;

- kategoria „Najlepsze Przedsięwzięcie w Odnowie Wsi”: Stary Wielisław - I miejsce w 2016 r. 
Kolejną korzyścią dla wsi jest wykorzystanie budynków związanych niegdyś z rolniczym charakterem, a dziś już często opuszczonych. Dzięki nowej funkcji wiele z tych obiektów zostaje uratowanych przed całkowitym zniszczeniem. W ten sposób zostają zaadaptowane stodoły czy inne budynki gospodarcze, związane z przetwórstwem czy dawnym rzemiosłem, ale także opuszczone czy sporadycznie wykorzystywane, niepełniące obecnie konkretnej funkcji, obiekty gminne, którym ofiarowane jest „drugie życie”. Przykład może stanowić wieś Spytków, w której pod funkcjonowanie wioski tematycznej poprzednia Pani sołtys udostępniła swoją stodołę, służącą integracyjnym spotkaniom lokalnej społeczności, czy do prowadzenia warsztatów, a nawet przyjmowania grup studyjnych. I choć już od 4 lat funkcjonuje we wsi świetlica w nowo wybudowanym budynku gminnym, wspomniana stodoła nadal pełni nadrzędną rolę w funkcjonowaniu tamtejszej wioski tematycznej.

Wszystkie badane wioski tematyczne oferują płatną ofertę pobytową, która zasila budżet działającej we wsi fundacji czy stowarzyszenia. Nie jest to jednak dochód stały, lecz sezonowy, najczęściej od późnej wiosny do wczesnej jesieni. Najwięcej klientów przybywa przede wszystkim w czerwcu i wrześniu, ale coraz częściej również w okresie wakacyjnym (lipiec-sierpień), podczas którego przyjmowane są grupy półkolonii, a także dzieci z opiekunami, którzy spędzają wakacje w pobliskich miejscowościach. Ciekawą inicjatywą, dającą wsi realne dochody, jest klastrowanie lokalnych usług turystycznych w Krainie Wygasłych Wulkanów w postaci organizowanych w okresie wakacyjnym zajęć „Warsztaty Rodzinne w Krainie Wygasłych Wulkanów". Inicjatywa ta skupia m.in. zagrody edukacyjne czy wioski tematyczne oferujące swój program twórczy. Biorą w niej udział również 2 badane wsie - Chrośnica i Radzimowice, które oferują płatne warsztaty tematyczne związane ze swoją specjalizacją w wybrane dni tygodnia, przez cały okres wakacji.

\section{Podsumowanie}

Tradycyjny, rolniczy charakter obszarów wiejskich odchodzi już coraz częściej w zapomnienie. Wsie szukają nowych możliwości rozwoju poza sektorem rolniczym. Coraz bardziej popularną w Polsce formą innowacji w turystyce wiejskiej są wioski tematyczne, które promują obszary wiejskie i przyciągają na ich tereny coraz więcej turystów (jak dowodzą badania, nawet do 5 tys. osób rocznie). Jest to dobry sposób na ożywienie gospodarcze regionu, które daje korzyści obu stronom. Zyskują zarówno turyści, jak i mieszkańcy wsi. Ci pierwsi otrzymują możliwość obcowania z przyrodą. Proponowany program służy zarówno rozrywce, jak i zachęca do nauki, stąd można stwierdzić, że współczesna wieś to doskonałe miejsce do edukacji i zabawy. Programy edukacyjne oferowane przez wsie adresowane są do różnych grup, ale przede wszystkim korzystają z niego, najbardziej chłonne wiedzy, dzieci i młodzież w wieku szkolnym (69\% odwiedzających). Dużym problemem jest słaba promocja wiosek tematycznych. Trudno jest dotrzeć do ich oferty, dlatego najczęstszymi gośćmi są osoby mieszkające w promieniu do 50 km, którzy o funkcjonowaniu wioski dowiadują się od znajomych drogą "szeptaną".

Proponowane przez wsie zajęcia w terenie, ze względu na możliwość bezpośredniego kontaktu ze środowiskiem naturalnym, prócz cennych wartości poznawczych dostarczają także wielu przeżyć emocjonalnych. Coraz popularniejszym trendem jest wzrost popytu na turystykę doznań i emocji. Turyści szukają coraz częściej aktywności, nauki oraz nie- 
typowych wrażeń, których wioski tematyczne są w stanie im dostarczyć. Priorytetem nie jest już często wygoda i bezpieczeństwo, ale wiedza, doświadczenie, wyjątkowe doznania, przeżycia i emocje. Zmieniają się przy tym preferencje turystów, którymi staje się rekreacja czynna, atrakcje kulturalne, historyczne, walory przyrodnicze, chęć powrotu do korzeni i tradycji, które są często motywem przewodnim badanych wsi i budują ich ofertę. Oferowany program edukacyjny opiera się w głównej mierze na warsztatach tematycznych. Tematy warsztatów można przyporządkować do poszczególnych rodzajów: kultywowanie tradycji i miejscowej kultury, poznawanie miejscowej fauny i flory czy dawne rzemiosło. Oprócz punktów stacjonarnych wsie proponują również szeroką ofertę angażującą przestrzennie większe obszary wsi. Turyści mogą skorzystać m.in. z questów, gier terenowych, ścieżek edukacyjnych, ścieżek zmysłów, tablic edukacyjnych, geocatchingu, zwiedzania wsi z przewodnikiem, wykładów, prelekcji, pogadanek tematycznych, zajęć rekreacyjno-sportowych, a także mogą uczestniczyć w świętach lokalnych. Wszystkie wymienione wyżej punkty programu bazują na obranej przez wieś specjalizacji.

Funkcjonowanie wioski tematycznej nie byłoby możliwe bez zaangażowania się w nią jej mieszkańców. Najczęściej zaangażowanych jest około 5 osób, ale zdarzają się wsie, w których liczba zaangażowanych wzrasta do kilkunastu. W badanych miejscowościach funkcjonowanie wioski tematycznej może stanowić alternatywne źródło dochodu, gdyż każda z analizowanych wsi posiada ofertę komercyjną. Z przeprowadzonych badań wynika, że zajęcia edukacyjne prowadzone w poszczególnych wioskach tematycznych przynoszą korzyści finansowe lokalnym społecznościom. W zależności od liczby odwiedzających wieś tematyczna może zarobić od 1500 zł do nawet 125 tys. zł rocznie. Nie jest to jednak dochód regularny, pojawia się głównie w miesiącach czerwiec-wrzesień. Aktywność wiosek tematycznych jest często zauważana również na zewnątrz. Mieszkańcy zaczynają dbać o zagospodarowanie przestrzenne wsi, zarówno pod katem zieleni, jak również zabudowy. Wioski te często biorą udział w konkursach o randze wojewódzkiej, w których odnoszą sukcesy. W konkursach tych oceniana jest zarówno aktywność mieszkańców, jak również dbałość o ład przestrzenny, co służy poprawie wyglądu wsi i wzrostowi aktywności społecznej, a co za tym idzie, zwiększeniu poczucia dumy ze swojego miejsca zamieszkania.

\section{Literatura}

Antoszek J., Sobczyk W., 2004, Możliwości uzyskiwania alternatywnych dochodów poprzez rozwój agroturystyki na obszarach wiejskich Lubelszczyzny, [w:] E. Pałka (red.), Alternatywne źródła dochodów gospodarstw rolnych, Instytut Geografii Akademii Świętokrzyskiej, Kielce, s. 43-51.

Buchcic E., 2014, Edukacja przyrodnicza elementem procesu wychowania, Studia Ecologiae et Bioethicae, UKSW, 12, 2, s. 27-43.

Budniak A., 2009, Edukacja społeczno-przyrodnicza dzieci w wieku przedszkolnym i młodszym szkolnym, Impuls, Kraków.

Czapiewska G., 2012, Wioski tematyczne sposobem na aktywizację gospodarczq i społecznq regionu, Studia i Materiały. Miscellanea Oeconomicae, 16, 1, Uniwersytet Jana Kochanowskiego w Kielcach, s. 109-123.

Czapiewska G., 2018, Wioski tematyczne w procesie odnowy wsi pomorskich, Studia Obszarów Wiejskich, 49, s. 155-172. 
Czarnecka B.M., 2007, Przygotowanie rolników do prowadzenia edukacji dzieci w ramach działalności agroturystycznej, [w:] J. Sikora (red.), Turystyka wiejska a edukacja-różne poziomy, różne wymiary, Wydawnictwo Akademii Rolniczej w Poznaniu, Poznań, s. 149-150.

Grykień S., 2006, Możliwości rozwoju agroturystyki na Ziemi Kłodzkiej, [w:] E. Pałka (red.), Gospodarka wielofunkcyjna ze szczególnym uwzględnieniem obszarów górskich, Instytut Geografii Akademii Świętokrzyskiej, Kielce, s. 69-76.

Kłodziński M., 2010, Główne funkcje polskich obszarów wiejskich z uwzględnieniem dezagraryzacji wsi i pozarolniczej działalności gospodarczej, Studia BAS, 24, 4, s. 9-27.

Kruczek Z., 2011, Atrakcje turystyczne. Fenomen, typologia, metody badań, Proksenia, Kraków.

Kutkowska B., 2012, Nowe funkcje obszarów wiejskich na przykładzie terenu sudeckiego. Nierówności społeczne a wzrost gospodarczy, 29, s. 97-110.

Idziak W., 2008, Wymyślić wieś od nowa. Wioski tematyczne, Alta Press, Koszalin.

Pałka E., 2010, Rola funkcji turystycznej w strukturze funkcjonalnej obszarów wiejskich w Polsce, Infrastruktura i Ekologia Terenów Wiejskich, 2, PAN, Kraków, s. 97-106.

Podolska A., 2018, Rozwój obszarów wiejskich w oparciu o ideę tworzenia wiosek tematycznych, Studia Obszarów Wiejskich, 49, s. 139-154.

Podolska A., Niedźwiecka-Filipiak I., 2016, Wpływ wsi tematycznych na wizualne aspekty krajobrazu wsi, Prace Komisji Krajobrazu Kulturowego, 34, s. 115-134.

Sala S., 2006, Agroturystyka a rozwój regionalny w dobie globalizacji, [w:] E. Pałka (red.), Gospodarka wielofunkcyjna ze szczególnym uwzględnieniem obszarów górskich, Instytut Geografii Akademii Świętokrzyskiej, Kielce, s. 57-68.

Salamon S., 2006, The Rural Household as a Consumption Site, [w:] P. Cloke, T. Marden, P. Mooney (red.), Handbook of Rural Studies, Sage Publications, London, Thousands Oaks, New Delhi.

Sikorska-Wolak I., Krzyżanowska K., Parzonko A., 2014, Doradztwo w zmieniajq̨cej się sytuacji społeczno-ekonomicznej obszarów wiejskich, Wydawnictwo SGGW, Warszawa.

Sikorska-Wolak I., Zawadka J., 2014, Innowacyjne rozwiqzania w turystyce wiejskiej, Stowarzyszenie Ekonomistów Rolnictwa i Agrobiznesu, 18, 4, s. 207-212.

Wilkin J., 2005, O potrzebie i założeniach długookresowej wizji rozwoju wsi w Polsce, [w:] K. Zawalińska (red.), Rozwój obszarów wiejskich. Doświadczenia krajów europejskich, IRWiR PAN, Warszawa, s. 45-56.

Wilkin J., 2010, Wielofunkcyjność rolnictwa. Kierunki badań, podstawy metodologiczne i impilkacje praktyczne, Wydawnictwo IRWiR PAN, Warszawa.

Woods M., 2005, Rural Geography, Sage Publications, London, Thousand Oaks, New Delhi.

Woś A., Zegar J.S., 2002, Rolnictwo społecznie zrównoważone, Wydawnictwo IERiGż, Warszawa.

Zegar J.S., 2002, Kwestia dochodów chłopskich, [w:] Ubezpieczenia w rolnictwie, Materiały i Studia, 13, 1, Warszawa, s. 65-79.

\section{Summary}

For some time, a number of changes - caused by both internal and external factors have been observed in rural areas. These mostly lead to modifying existing functions of the village. A typical model of agricultural village is becoming less common. Livelihood is more often provided by non-agricultural activities. These generate new jobs, integrate residents, interfere with the surrounding, and in many cases completely change the image of the village and the way it is being perceived. Villages are becoming active, innova- 
tive and creative. Ideas concern both economic as well as social activities and contribute to the rapid development of tourist and recreational values of the region. One of the new functions of the village, which in the recent years has become more popular is establishing thematic villages. A well-conceived leitmotif can bring benefits to both residents who find new jobs and additional source of income for themselves, as well as tourists who now have the opportunity of spending their free time in a more attractive way. It also fosters ecological education of children and youth who may learn about the surrounding nature. Rural space may also benefit, while their conscious residents will cultivate tradition and local culture respecting spatial order.

The aim of the research was to examine the role that the new non-agricultural function - thematic village plays in the development of rural areas of the Lower Silesia and their potential contribution in promoting educational tourism in the region. The research method was based on the analysis of source literature and statistical data contained in the registration books, as well as on surveys with rural leaders and analysis of available offers of selected thematic villages. 